\title{
PROTECTION OF THE PUBLIC INTEREST AND THE TAXPAYER'S INTEREST AS THE GOAL OF TAX ADVISORY IN POLAND
}

\author{
ELŻBIETA A. AMBROŻEJ ${ }^{l}$
}

\begin{abstract}
This article is related to the function of tax advisory in Poland, which is to protect the public interest and the taxpayer's interest. The article shows that it is not possible to clearly define the scope of this function (the purpose of tax advisory), which results from the character of the concepts of "public interest" and "taxpayer interest", which are general clauses. However, the article presents the values recognized in doctrine and judicature that fall within these clauses and are subject to protection. The main aim of the article is an attempt to prove that the current legal model of tax advisory in Poland poses threats both to the taxpayer's interest and public interest, in particular by an improper shape of the principles of tax advising as well as the ones of acquiring the right to exercise it. The research used a dogmatic-legal research method and analysis of the jurisprudence of the Constitutional Tribunal and the judiciary, mainly administrative.
\end{abstract}

\section{Keywords}

Tax advisory; public interest; taxpayer's interest; protection of public interest; protection of the taxpayer's interest

JEL Classification: E62, H24, K34

\section{Introduction}

The Tax Advisory Act to meet social needs, created a new profession of public trust - a tax advisor. As argued in the explanatory memorandum to the draft of this law

1 Doctor of Law, Department of Finance and Accounting, College of Finance and Management in Bialystok, Poland. The author specializes in tax law and tax advisory. The author of numerous articles related to tax law and tax consulting. A member of the Center for Information and Organization of Public Finance Research and Tax Law of the Countries of Central and Eastern Europe. Contact email: elzbieta.ambrozej@gmail.com. 
(Draft no. 1113), providing tax advice and providing taxpayers with assistance in performing their duties (...) by persons without appropriate qualifications poses a threat to both the taxpayer's interests and the interests of the tax office. Misleading information on the existence of a tax obligation or the amount of tax liability exposes him to the consequences set out in the tax law, penal fiscal law and penal code, which, if the tax liability was significant, could lead to a threat of a taxpayer's economic capacity. Considering the above, it was stated that the statutory regulation of the principles of tax advisors' profession becomes, from the social point of view, an extremely important matter, and thus the creation of a new professional group recognized by the state, which would enjoy the great trust and social prestige.

The statutory construction of the tax advisor profession allows to include the profession in the public trust professions referred to in Art. 17/1 of the Constitution of the Republic of Poland. According to its content, the professions of public trust are those for which professional self-government bodies are created by the way of law, as well as representing persons performing them and exercising control over their proper performance, within the limits of public interest and for its protection. Professional corporations, therefore, have two constitutionally defined functions to fulfill. The first one is to represent the people performing such professions both towards citizens and their organizations, as well as against the state authorities. The second function comes down to efforts to ensure proper performance of these professions. It is implemented through supervision over the performance of a particular profession within the limits of public interest and for its protection, including, and perhaps above all, protection of citizens' rights (Constitutional Court: K 37/00).

In practice, the implementation of such a specific tax advisory goal has two main obstacles. The first one is the lack of a statutory definition of the terms "public interest" and "taxpayer interest", which in practice causes problems of interpretation and does not explicitly define the scope of the tax advisory goal ${ }^{2}$. An additional problem is that in the jurisprudence of the Constitutional Tribunal and administrative courts, the term "public interest" is often identified with "fiscal interest", "the interest of the Treasury" or "budgetary interest", which seems to 
Protection of the Public Interest and the Taxpayer's Interest as the Goal...

be a significant narrowing of the scope of the term "public interest". In relation to the notion of "taxpayer's interest", the narrowing of its significance is already highlighted by the Tax Ordinance Act which narrows it to the notion of "important taxpayer's interest" or "important interest of the party", which indicates the different scope of these concepts, and thus the various role of tax advisory in achieving its goal.

The second obstacle can be reduced to the thesis that the Tax Advisory Act, as it currently stands, poses a threat to effective protection of both public interest and taxpayer's interest, in particular through the deregulation of some of tax advisory activities, improper shaping of the rules for acquiring the right to practice as a tax advisor. In order to show the cited threats, it is necessary to attempt to identify the meaning of the terms "public interest" and "taxpayer's interest", their mutual relations, as well as the reference of these concepts to tax advisory institutions.

\section{Notion of Public Interest}

According to the Polish dictionary (www.sjp.pwn.pl), "interest" is a benefit, someone's good and benefits. In the broader, linguistic sense of "interest" the relationship between an objective, current or future state and the evaluation of this state from the point of view of the benefits that it brings or can bring to any individual or social group should be comprehended (Lang, 1972: 98-100). The phrase "public" means, on the other hand, referring to the whole society or some collective bodies, and available or intended for everyone, or related to some office or some kind or a non-private institution (www.sjp.pwn.pl).

In the doctrine of tax law and the jurisprudence of administrative courts, "public interest" is most often understood as a directive of conduct, requiring that the common values of the whole society or local community (territorial self-government unit) are respected, such as justice, security, citizens' trust in the authorities public authority, efficiency of the state apparatus, etc. (Presnarowicz, 2002: 86; Supreme Administrative Court: II FSK1610/13). It is emphasized that these values are not of a permanent nature, hence the content of public interest is variable over time, depending on the will of the democratic majority - but within the limits of the state's obligations expressed in the Constitution and laws (Dębowska-Romanowska, 2002: 20). The unclearness and changeability of the public interest cause that the legislator using this concept transfers the burden of defining its content in a specific case to the authority applying the law, whose duty is to find its content.

The literature also claims that the "public interest" is part of the broader concept of "common good", in the name of which people join and form the state, establish 
a state, (...) the common good is realized in cooperation - that is, co-creation and sharing (Dębowska-Romanowska, 2010: 19). However, it is also necessary to resort to state coercion (Dębowska-Romanowska, 2010: 19-20). This understanding of the public interest forms the basis for limiting freedom and civil rights (Constitutional Court: K.28/01). There are duties and sacrifices here which are connected to the obligation of citizens to pay public levies, including taxes referred to in art. 84 of the Constitution. However (...), the regulations governing the issue of public tributes must be compatible with all of the existing norms and constitutive principles. They cannot lead to any violation of values subject to constitutional protection. In particular, they cannot form a tax obligation in such a way that it would become an instrument of confiscation of property (Constitutional Court: SK.49/06).

With regard to public finances, the Constitutional Tribunal has also repeatedly emphasized that the public interest manifests itself in particular in the need to protect the stability of the state's financial interests and preserve budget balance (Constitutional Court: K.1/12), and case law of Administrative courts formulate the thesis that the public interest is not only the need to provide the necessary income in the budget but also to limit its possible expenses, e.g. for unemployment benefits or social welfare assistance (Supreme Administrative Court: III SA 830/00). In the jurisprudence of the Supreme Court, one can find a view that the notion of public interest should not be directly identified with the economic or fiscal interest of the state (Supreme Court: III ARN 33/93).

Referring to the position of the doctrine in the presented issue, one should also indicate an opinion according to which the public interest also refers to cases where there is a need to withdraw from the legislator's mistakes, resulting in the unpaid tax arrears (Modzelewski, 1997: 79). It is also worth noting that the public interest should also be sought in behaviours aimed at protecting or promoting the principles contained in the Constitution (Zdebel, 2012: 199-200), because in a democratic state of law every attempt to realize constitutional values is in the public interest (Bartosiewicz, Kubacki, 2007: 49). These principles (values) include, in particular, the principle of nullum tributum sine lege (Constitution, 217), which sets the limits of state interference in civil rights and freedoms and is of a guarantee nature, i.e. aimed at protection of individual rights (Supreme Administrative Court: I FSK 871/08). These values should also include all principles resulting from the principle of a democratic state ruled by law, in particular, the principle of protection of trust in the state and its law.

The literature also claims that the "public interest" can be seen as a tool for shaping the situation of the individual, since every state and self-government action is ultimately addressed to a man, hence the public interest can be described 
Protection of the Public Interest and the Taxpayer's Interest as the Goal...

as potentially related to many non-individual recipients treated as common entity (Boć, 2000: 23-24).

\section{Concept of Taxpayer's Interest}

Determining the meaning of the term "taxpayer interest" requires referring to the meaning of the term "individual interest". Considering the dictionary meaning of the phrase "interest" and the meaning of the phrase "individual", i.e. appropriate only to one person or individual, it should be assumed that in an etymological sense individual interest is the benefit, good and gains regarding specific individuals.

In the literature, in particular, with regard to an individual subject, it is argued that the concept of "interest" can be defined as the need, i.e. the desire (pursuit) to achieve an advantage that is able to enable a given entity to survive and develop in a given social environment. In this sense, the benefit means participation in goods that are in a limited quantity, i.e. unevenly distributed. In addition, this concept should include situations in which the purpose is not only to obtain a good but also to avoid the danger of violation of some of its interests (including reducing or preventing losses (Wilczyńska, 2009: 48-49).

Speaking of interest as a legal category, and in particular of the taxpayer's interest, in legal doctrine and jurisprudence, it is most often understood as a certain state of expectation, a specific need to preserve benefits already possessed or to wait for a good to appear (Presnarowicz, 2002: 68 et seq.). This concept should be associated with the dignity of the taxpayer, the possibility of further running a business, ensuring a decent life for himself and the closest family (Etel, 2017: 1472).

In tax legislation, the taxpayer's interest is referred to in particular in the Tax Ordinance Act. However, the subject of its regulation is not every taxpayer's interest, but an interest with specific features. The Tax Ordinance Act uses the phrases "important interest of the taxpayer" 3 and "important interest of the parties" ${ }^{\prime 4}$, which clearly indicates the interest of the taxpayer, which is crucial and of great importance (www.sjp.pwn.pl).

The lack of a normative determination of an important taxpayer's interest and an important interest of the party causes that these concepts are defined mainly in the case-law of administrative courts. Considering, however, that the condition of "important interest of the party" has a broader scope than the criterion

It may concern not only the taxpayer but also the payer, collector, third party responsible for tax arrears and legal successors of the taxpayer, payer, and collector. 
of "important taxpayer's interest", as well as the fact that the assessment of the existence of "important interest of the party" by administrative courts is most often related to the "important interest of the taxpayer", resulting from the substantive law provision constituting the basis of the final decision (Supreme Administrative Court: I GSK 366/136), hereinafter referred only to the concept of "important interest of the taxpayer".

The premise of an "important taxpayer's interest" is defined by administrative courts, in particular on the basis of tax reliefs. Under this concept, administrative courts understand extraordinary and fortuitous situations due to which the taxpayer is unable to regulate its public and legal obligations, and which could upset the taxpayer's existence basis (District Administrative Court: I SA/Wr 735/02). This will include loss of earning opportunities, contingent loss of fortune (Supreme Administrative Court: SA/Sz 850/98). However, when considering whether the taxpayer's interest is important, it is necessary to take into account, in addition to extraordinary (contingent) situations, also his economic situation (Supreme Administrative Court: I FSK 31/08), including the amount of income and expenses (Supreme Administrative Court: II FSK 3139/13), while the notorious lack of cash for payment of tax is not a prerequisite of the taxpayer's interest (District Administrative Court: III SA 2919/03).

An important taxpayer's interest concerns the situation of an individual taxpayer, but his important interest must be so significant and exceptional that its omission would have negative consequences for him (Choduń, Gomułowicz, Skoczylas, 2013: 118).

Analysis of the main thesis of administrative court rulings suggests that the existence of the "important taxpayer's interest" is assessed by the courts through objectified criteria, consistent with the generally approved hierarchy of values to which health and life belong, as well as earning opportunities to obtain means of subsistence of oneself and one's family, and well as the threat to existence. It is also important that the existing circumstances are independent of the taxpayer's behavior or caused by factors beyond the control of the taxpayer (District Administrative Court: I SA/Wr 735/02).

The taxpayer's interest, understood as a state of waiting for a certain advantage or the need to preserve the benefits already possessed or to wait for the emergence of a certain good, can, therefore, be referred to both the sphere of law-making and

6 In the above judgement, The Supreme Administrative Court stated: Admissibility of a change of final decision pursuant to Art. 253a/1 Tax Ordinance Act, except of meeting the conditions defined in this procedural law, depends on the content of this substantive law, on the basis of which the legal situation of a party in a given case is shaped, while both public and important interest of the party are evaluated from the perspective of the substantial law provision constituting the legal basis for the final decision. 
Protection of the Public Interest and the Taxpayer's Interest as the Goal...

application. In the sphere of action, the taxpayer's interest will be in particular the state of expectation that the legislator will create law respecting all constitutional principles, in particular, the principle of the rule of law (Constitution, Art. 7), and all values arising from the principle of a democratic state of law (Constitution, Art. 2). The taxpayer is obliged to fulfill his obligations, including the payment of tax, but only in the amount, time and place resulting from the provisions of tax acts. The special nature of tax law, directly interfering with the sphere of freedom and property of a taxpayer, therefore requires the formulation of tax law in a clear and precise manner, so that the taxpayer can comprehend the content of tax obligations that he is responsible for (fiscal, tax and criminal, and criminal). This interest also includes stability and certainty of tax law, shaping current or future taxpayer behaviour, hence the taxpayer's interest is to provide him with the possibility of appropriate tax planning, which should be expressed in the obligation to introduce a new law with the establishment of appropriate vacatio legis and transitional provisions, is to provide the taxpayer with the protection of "ongoing interests" (Constitutional Court: P 43/07).

In the field of tax law, the taxpayer's interest may be related to the possibility of taking all actions foreseen by law, both during and outside the tax procedure, which may give the taxpayer a certain advantage and thus protect the rights granted to him under the Constitution and tax law, both general and detailed.

\section{Public Interest and Taxpayer's Interest}

In the literature, "public interest" is also defined by comparing it with the concept of "individual interest", by which the taxpayer's interest should also be understood. The combination of these two interests can lead to tensions between them, their competitiveness and collisions (Zimmermann, 2005: 262) 7 .

Currently, in the doctrine and jurisprudence of the Constitutional Tribunal and administrative courts prevails the view that one cannot unequivocally attribute the superiority of the public interest over the interest of the taxpayer, both these interests must be balanced in every situation. This means that sometimes priority will be in the public interest and sometimes it will have to give way to individual interest (Żurawik, 2013: 57). It seems, however, that in a democratic state of law, the task of the administration should be to strive within the framework defined by law

$7 \quad$ It is noticed that there may be various relations between the public interest and the individual interest, which are recognized as overlap (these interests are completely identical); contradiction (disharmony) of public and individual interests (these interests abolish each other); indifference, these interests remain completely neutral with each other - they function on parallel planes, without being in conflict with each other (Wieloński, 2012: 21; Wilczyńska, 2009: 48-55). 
(in particular, the sphere of administrative recognition) to harmonize or reconcile both interests (Kmieciak, 1991). One should also agree with the opinion expressed in the doctrine that the protection of individual interests is in the public interest, that is, institutional securing protection and the possibility of pursuing their interests by individuals serves the collective body (Wieloński, 2012: 21). In this sense, the protection of the taxpayer's interest by the tax advisory institution (tax advisors) is also in the public interest.

\section{Tax Advisory Institution and Protection of Public Interest and Taxpayer's Interest}

Article 84 of the Constitution of RP, imposes on everyone an obligation to bear public burdens and benefits, including taxes specified in the Act. The concept of tax obligation in the light of Art. 84 of the Constitution of RP, has two aspects. The first of these relies on the taxpayer's obligation to meet (pay) the tax benefit (benefits) resulting from specific tax laws and from the general tax law, which may also provide for mandatory liability (co-responsibility) of other people for fulfilling (non-compliance) tax benefit. The second aspect is the personal and, at the same time, the economic obligation of maintaining one's own country. It raises some duties and rights. On the one hand, it is about being ready not only to bear the tax burden, but also other auxiliary duties accompanying it - on the other, to protect the dignity of a taxpayer acting in good faith, as a person maintaining the state, its privacy and the right to help the state to fulfil its duty (Dębowska-Romanowska, 2010: 140-141).

The aspect of tax obligation understood in this way allows to state that one of the forms of state aid in implementing tax obligations imposed on taxpayers is the establishment of a tax advisory institution. The tax advisor acts as a liaison between the taxpayer and the tax authority representing the public-law entity and therefore has two main goals to fulfill. The first one is to lead to the proper implementation of tax obligations incumbent on the taxpayer, including payment of tax in the amount, time and place resulting from the provisions of tax law. This is to protect the taxpayer's interest, in particular by protecting his property rights, as well as to prevent the taxpayer from being liable to tax, criminal-fiscal or criminal liability. Tax advisors, while protecting the taxpayer's interest, consequently protect the public interest as correctly and timely charged and paid taxes to ensure a permanent inflow of funds to the state budget and budgets of local government units necessary for the implementation of public expenditure specified in these budgets. This function is, therefore, the second aspect of tax advisory. A condition for the effectiveness of tax advisory (proper implementation of the tax advisory objective) 
is the existence of such a system of legal norms that will ensure the necessary protection of the tax advisor's rights and interests, public interest as well as the tax advisor's client - the taxpayer's interest.

The Tax Advisory Act on during the 20 years of its implementation has undergone significant modifications. For the most part, these modifications served both the public interest and the taxpayer's interest. The subject-related and subjective scope of tax advisory activities has been extended, which means that the institutional protection of tax advisory covers a wider range of entities and tax matters. Tax advisors were granted a catalog of new rights, such as material immunity, the right to Authorize copies of documents, the right to provide substitution within their own profession and as a lawyer and legal advisor. The protection of the professional secrecy of the tax advisor has been strengthened (it is unlimited in time, and only the court may exempt from the obligation to maintain it). Tax advisors obtained the right to practice in the form of all types of commercial companies, including multidisciplinary involving attorneys, legal advisors, statutory auditors and foreign lawyers, which ensured the possibility of comprehensive customer service in one law firm. The role of the advisors' professional self-government has been strengthened, thus also affecting the practice of tax advisor profession, which fulfilled the directive of the Constitution, Art. 17/1 - ensuring custody over the due performance of the profession, within the public interest and for its protection.

The major change took place with the entry into force of the Act of 9 May 2014 on facilitating access to certain regulated professions, hereinafter referred to as the "deregulation act". This Act, in particular, changed the principles of performing tax advisory activities, the acquisition of rights to practice as the tax advisor, as well as the forms in which this profession can be exercised.

Art. 2/1 of the Tax Advisory Act which had been in force just before the Deregulation came into force, included the following tax advisory activities:

1) providing taxpayers, taxable persons, and collectors with, at their direction or on their behalf, advice, opinions and explanations regarding their tax and customs obligations as well as administrative enforcement related to these duties,

2) keeping, on behalf of and for the benefit of taxpayers, taxable persons and collectors, tax books and other records for tax purposes and providing assistance in this regard,

3) preparing, on behalf of and for taxpayers, taxable persons and collectors, testimonies and tax returns or providing assistance in this respect,

4) representing taxpayers, taxable persons, and collectors in proceedings before public administration authorities and in the scope of judicial review 
of decisions, resolutions and other administrative acts in the matters listed in point $1 .^{8}$

The professional performance of tax advisory activities was reserved only to entities Authorized under the Act, i.e. tax advisors, lawyers, legal advisors, as well as auditors, in the scope specified in the Tax Advisory Act (Art. 2/2) .

In addition, in the light of the Accounting Act also entities providing accounting books were entitled to keep tax books and other records for tax purposes and preparation of tax returns and declarations (Accounting Act, Art. 76a/2). The performance of these activities by certified accountants did not violate the provisions of the Tax Advisory Act, because these activities, although coinciding with tax advisory activities, were not such and were not subject to the tax advisory act. What is important, the condition to acquire the right to provide bookkeeping services was to obtain an accountancy certificate (Accounting Act, Art. 76a/4), issued by the Minister of Finance, after fulfilling by the interested party a number of requirements specified in the $\mathrm{Act}^{10}$.

The deregulation act has liberated two extremely essential, from taxpayer's point of view, tax advisory activities, i.e. keeping tax and other records for tax purposes, and preparing tax returns and declarations. This regulation should be assessed negatively. Significant seems to be here the disturbance of the proportion between the purpose of this regulation and its possible consequences. The legislator, in order to influence the labor market, reduce unemployment, provide easier and wider access to tax advising, while abolishing the accounting certificate, opened the way for the provision of these services by any person, regardless of professional qualifications and personal qualities, with no public supervision whatsoever.

The proper keeping of tax books, their proper storage as well as timely notification of the tax authority about entrusting the keeping of tax books is important for the taxpayer both to determine the tax base and to prepare tax returns, but also to avoid fiscal, criminal and criminal tax liability. Hence, the quality of these books, the security of taxpayers and the protection of their interests depends on the qualifications of the people who maintain them. Transferring the right to maintain them to persons who are not duly prepared for it may lead to incorrect entries in

8 These activities could also be performed for third parties responsible for tax arrears and legal successors of taxpayers, payers or collectors (Tax Advisory Act, Art. 2/1a).

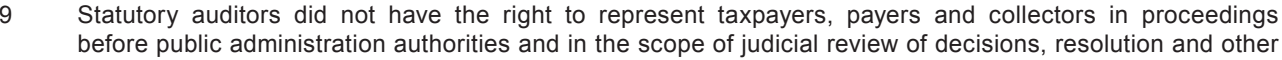
administrative acts.

10 These included full legal capacity, not being convicted by final judgment for particular offenses (including against the credibility of documents, property, business transactions, for criminal-fiscal offenses), professional tertiary education, professional practice, and in relation to persons who did not have a higher education degree passing the exam confirming the qualifications (Accounting Act, Art. 76b). 
Protection of the Public Interest and the Taxpayer's Interest as the Goal...

them, and thus the risk of recognition of the documentation as unreliable arises. This serves to protect neither the taxpayer's interest nor public interest.

Tax advisor's wide range of interdisciplinary knowledge and practical skills is a prerequisite for the proper performance of the profession. The Tax Advisory Act provides in this respect two basic requirements for future tax advisors the obligation to pass an exam to become a tax advisor and to complete an apprenticeship.

Professional training as the last stage of acquiring professional qualifications makes it possible to verify the actual skills of the candidate for the profession. Its completion is necessary to ensure the high quality of services provided, and thus protect the interests of the taxpayer as well as the public interest. Until the entry into force of the deregulation act, the candidate for a tax advisor was obliged to complete a two-year internship ${ }^{11}$ in Poland, which was to prepare him for practicing his profession, familiarize with all aspects of future work, the functioning of tax authorities and tax advisory. Such a purpose of the apprenticeship meant that it took place in the tax authorities, i.e., successively, in the tax office, tax chamber and in the fiscal control office, for a period of two months in each of them, as in a tax advisor or in a tax advisory company for 18 months $^{12}$. The deregulation act has shortened the apprenticeship to 6 months. In principle, its character and purpose have also changed. At present, the purpose of the internship is to familiarize the candidate with the profession of a tax advisor, therefore the employer has consistently limited the place of the apprenticeship to a tax advisor or a tax advisory company (Tax Advisory Act, Art. 21/4). In addition, 8 hours a week work time limit ${ }^{13}$, meaning that the actual internship was reduced to 26 days. It seems that such a far-reaching shortening of the apprenticeship does not ensure the implementation of its statutory goal. It is not possible to learn the practical aspects of this complex and interdisciplinary profession in such a short time. Therefore, it should be recognized that this regulation poses a threat to the clients of tax advisors and the protection of their interests, as it allows the profession to be performed by persons who are not properly prepared for it.

In addition to the apprenticeship, an exam for a tax advisor is part of the process of verifying the candidate's preparation for the profession. Starting from 10 August 2014, the Examination Commission with regards to the principles of conducting

11 The exceptions In this regards concerned natural persons whose qualifications to perform the profession of a tax advisor were recognized on the principles set out in the Act of 18 March 2008 on the principles of recognition of professional qualifications acquired in the European Union Member State.

12 Regulation of the Minister of Finance on 17 November 2010 on apprenticeship of candidates for tax advisors, $\S 2$ (1).

13 Detailed rules of Professional apprenticeship are regulated by the Regulation of Minister of Finance on 5 October 2014, on the professional apprenticeship of the candidate for tax advisors. 
tax advisor examination has obtained a new, extremely important entitlement. In the verification proceedings, university graduates with whom the Examination Commission will conclude the agreement ${ }^{14}$ will be able to take an exam to become a tax advisor on concessional terms, consisting in the possibility of exemption from the written part of the examination. This privilege, however, is limited in time and lasts no longer than two years after graduation (Tax Advisory Act, Art. 25/5 and Art. 25/6) ${ }^{15}$.

This solution should be considered beneficial, both for the development of tax advisory, protection of the taxpayer's interest, as well as the public interest. It creates the basis for shaping the common academic education of candidates for tax advisors. Currently, this profession can be performed by people regardless of the type of higher education they have, which seems not to protect the taxpayer's interest or public interest. It seems that the specificity of this profession requires that the candidate should at least have an economic, legal or specialized education, created for the needs of future tax advisors.

Doubts are also raised by the ban on the profession of a tax advisor as part of employment with an entrepreneur, which was abolished by the Deregulation Act. Characteristics of the employment relationship - subordination and submission of the employer's to the employee may affect the lack of independence and autonomy of the tax advisor in the profession, which violates the essence of the profession of public trust established for the protection of public interest (Constitution, Art. 17/1) and, consequently, also the taxpayer's interest.

\section{Conclusions}

The analysis of the meaning of "public interest" and "taxpayer's interest" led to the conclusion that these concepts do not have a fixed and unambiguous meaning, which imposes on the authorities that exercise law the right to interpret these concepts and look for their meaning in a specific situation. However, they cover certain superior values that require protection. Both doctrine and jurisprudence indicate it. It allows stating that apart from the state and local self-government as well as bodies acting on their behalf, the institution that can protect both these interests is the institution of tax advisory. It seems, however, that this goal is currently not fully implemented. Although tax advisors fulfill their basic function by providing taxpayers with

\footnotetext{
14 These agreements may be concluded only by those universities which organizational units are authorized for the postdoctoral degree in economics or legal sciences and which educational curriculum covers knowledge and skills required in the written part of the examination of a tax advisor. university graduate will become out of date.
} 
Protection of the Public Interest and the Taxpayer's Interest as the Goal...

assistance in fulfilling their tax obligations, incorrectly shaped provisions of the Tax Advisory Act, in particular allowing some tax advisory services to be carried out by persons with unconfirmed formal qualifications, poses serious threats to taxpayers' interests, and protection of their rights. An additional risk is the complete lack of public supervision over the performance of these activities by persons who are not members of professional corporations (people who maintain accounting books). For this reason, it is desirable to amend the provisions of the Tax Advisory Act in the above-mentioned scope, which will contribute to strengthening the protection of the taxpayer's interest as well as the public interest.

\section{References}

Bartosiewcz, A., Kubacki, R.: Ulgi płatnicze w świetle wartości konstytucyjnych (Payment allowances in the light of constitutional values), Monitor Podatkowy (Tax Monitor) no. 12 (2007).

Boć, J. et al.: Prawo administracyjne (Administrative law), Wrocław: Kolonia Limited, 2000.

Choduń, A., Gomułowicz, A., Skoczylas, A.: Klauzule generalne i zwroty niedookreślone w prawie podatkowym i administracyjnym. Wybrane zagadnienia teoretyczne i orzecznicze (General clauses and under-defined phrases in tax and administrative law. Selected theoretical and judicial issues), Warszawa: Wolters Kluwer, 2013.

Dębowska-Romanowska, T.: Zarys prawa. Prawo Finansowe. Część konstytucyjna wraz z częścią ogólną (Outline of law. Financial law. The constitutional part along with the general one), Warszawa: C.H. Beck, 2010.

Etel, L. et al.: Ordynacja podatkowa. Komentarz (Tax Ordinance Act. Comment) Warszawa: Wolters Kluwer, 2017.

Kmieciak, Z.: Glosa do wyroku NSA z dnia 8 stycznia 1988 r., sygn. akt: IV SA 753/87 (Gloss of NSA rulling of January 8, 1988, case ref. II SA 753/87) Orzecznictwo Sądów Polskich (Polish Courts Jurisdiction) no. 7-8, item. 15 (1991).

Modzelewski, W.: Ordynacja podatkowa w pytaniach i odpowiedziach, Tom I (Tax Ordinance Act, questions and answers), Warszawa: Instytut Studiów Podatkowych Modzelewscy i Wspólnicy, 1997.

Presnarowicz, S.: Ulgi i zwolnienia uznaniowe w Ordynacji podatkowej (Discretionary tax exemptions and reductions and in Tax Ordinance Act), Warszawa: Dom Wydawniczy ABA, 2002.

Wieloński, M.: Realizacja interesu publicznego w prawie zamówień publicznych (Realization of public interest in public procurement law), Warszawa: Wydział Dziennikarstwa i Nauk Politycznych Uniwersytet Warszawski, 2012.

Wilczyńska, A.: Interes publiczny $\mathrm{w}$ prawie stanowionym $\mathrm{i}$ orzecznictwie Trybunału Konstytucyjnego (Public interest in the law and case law of the Constitutional Tribunal), Przegląd Prawa Handlowego (The Commercial Law Review) no. 6 (2009). 
Zdebel, M.: Przesłanki umorzenia zaległości podatkowych należnych gminom (Premises for the write-off of tax arrears payable to municipalities), Annales Universitatis Mariae CurieSkłodowska, Sectio H, no. 3 (2012).

Zimmermann, J.: Przepisy ogólne prawa administracyjnego i definiowanie pojęć (General regulations of administrative law and defining concepts), Ruch Prawniczy, Ekonomiczny i Socjologiczny (Legal, Economical and Sociological Movement) no. 2 (2009).

Żurawik, A.: „Interes publiczny”, „interes społeczny”, i „interes społecznie uzasadniony”. Próba dookreślenia pojęć ("Public interest', "social interest" and "interest socially justified". An attempt to define the concepts), Ruch Prawniczy, Ekonomiczny i Socjologiczny (Legal, Economical and Sociological Movement) no. 2 (2013).

Internet Dictionary of Polish Language, Polish Scientific Publisher. www.sjp.pwn.pl

PL: Constitution of Republic of Poland of 2 April 1997, as amended.

PL: Tax Ordinance Act of 29 August 1997, as amended.

PL: Tax Advisory Act of 5 July 1996, as amended.

PL: Accounting Act of 29 September 1994, as amended.

PL: Act of 9 May 2014, as amended on Facilitating Access to Certain Regulated Professions.

PL: Constitutional Court: K.37/00.

PL: Constitutional Court: K.28/01.

PL: Constitutional Court: SK.49/06.

PL: Constitutional Court: P.43/07.

PL: Constitutional Court: K.1/12.

PL: Supreme Court: III ARN 33/93.

PL: Supreme Administrative Court: SA/Sz 850/98.

PL: Supreme Administrative Court: III SA 830/00.

PL: Supreme Administrative Court: I FSK 31/08.

PL: Supreme Administrative Court: II FSK1610/13.

PL: Supreme Administrative Court: II FSK 3139/13.

PL: District Administrative Court: I SA/Wr 735/02.

PL: District Administrative Court: III SA 2919/03. 